\title{
KONSUMSI TABLET BESI TERHADAP KADAR HEMOGLOBIN IBU HAMIL TRIMESTER DUA
}

\section{THE EFFECT OF IRON CONSUMPTION WITH HEMOGLOBIN LEVEL IN SECOND TRIMESTER PREGNANT WOMEN}

\author{
Romlah ${ }^{1}$, Anjelina Puspita Sari ${ }^{1}$ \\ ${ }^{1}$ Fakultas Ilmu Kesehatan, Unika Musi Charitas Palembang, Sumatera Selatan, Indonesia \\ (penulis korespondensi: ireneromlah@ukmc.ac.id)
}

Info Artikel: Diterima: 13 Februari $2020 \quad$ Revisi: 20 Mei $2020 \quad$ Disetujui: 15 Juni 2020

\begin{abstract}
ABSTRAK
Latar Belakang: Ibu hamil dengan anemia di Palembang masih membutuhkan perhatian khusus, hal ini terlihat dari masih meningkatnya kejadian anemia. Penelitian ini bertujuan untuk mengetahui Pengaruh Pemberian tablet Fe terhadap Kadar Hemoglobin Ibu Hamil Trimester Dua. Metode: Jenis penelitian observasional analitik dengan pendekatan pretest dan posttest control group desain. Populasi pada penelitian ini semua ibu hamil di wilayah kerja Kecamatan Ilir Timur I Palembang yang dilaksanakan mulai bulan November 2019-Januari 2020. Jumlah sampel dalam penelitian ini 16 responden. Teknik pengambilan sampel dengan Total Sampling. Teknik analisa data menggunakan analisis Uji Paired Sample T-Test.

Hasil: Hasil uji statistik menunjukkan bahwa rerata kadar Hemoglobin pada ibu hamil trimester II setelah konsumsi 30 tablet besi tidak ada perbedaan kadar rerata hemoglobin $(11.96 \pm 0,67 \mathrm{~g} / \mathrm{dl})$ dibanding dengan ibu hamil yang belum mengkonsumsi tablet besi $(12.26 \pm 0.99 \mathrm{~g} / \mathrm{dl})$ dengan nilai $p=0,079(>0,05)$, walaupun hasil statistik tidak ada perbedaan, tapi rentang kadar hemoglobin ibu masih dalam batas normal.

Kesimpulan: Berdasarkan hasil penelitian ini disarankan untuk tenaga kesehatan tetap menggalakkan pemberian Tablet besi terutama pada ibu hamil sesuai dengan program pemerintah yaitu 90 tablet selama kehamilan, hal ini penting karena konsumsi tablet besi pada ibu hamil untuk menjaga keseimbangan kadar zat besi pada ibu hamil sehingga mencegah anemia.
\end{abstract}

Kata Kunci : Ibu Hamil, Zat Besi, dan Kadar Hemoglobin

ABSTRACT:

Background: Pregnant women with anemia in Palembang still need special attention, this can be seen from the increasing incidence of anemia. This study aimed to determine the effect of iron consumption with hemoglobin level in second trimester pregnant women.

Methods: This type of observational analytical study used pretest and posttest control group design. The population in this study was all pregnant women in the working area at Kecamatan Ilir Timur I of Palembang which were conducted from November 2019-January 2020. The number of samples was 16 respondents. The sampling technique is total sampling. Data analysis technique was Paired Sample T-Test analysis.

Results: The results showed that the average hemoglobin levels in second trimester pregnant women after consumption of 30 iron not significant differences in mean hemoglobin level $(11.96 \pm 0,67 \mathrm{~g} / \mathrm{dl})$ compared to pregnant women who had not consumed iron $(12.26 \pm 0.99 \mathrm{~g} / \mathrm{dl})$ with $p$ value $=0,079(>0,05)$, Even though there are no statistical differences, the range of maternal hemoglobin levels is still within normal limits.

Conclusion: Based on the results, it is recommended that Health workers continues to promote iron tablets especially pregnant women in accordance with the government program, which is 90 tablets during pregnancy, this is important because the consumption of iron tablets in pregnant women to maintain iron balance in pregnant women thus preventing anemia.

Keywords: Pregnant, iron tablets, and haemoglobin 


\section{PENDAHULUAN}

Hemoglobin $(\mathrm{Hb})$ merupakan protein yang ada didalam sel darah merah, protein inilah yang memberikan warna merah pada darah. ${ }^{1}$ Ibu hamil yang memiliki kadar hemoglobin rendah atau kurang dari $11 \mathrm{~g} / \mathrm{dl}$ disebut anemia. ${ }^{2,3}$ Anemia ini terjadi saat kekosongan total besi dari cadangan (makrofag) dan dari eritroblas yang sedang berkembang. ${ }^{4}$ Program Pemerintah mewajibkan standar pelayanan asuhan antenatal salah satunya dengan pemberian tablet $\mathrm{Fe}$ atau zat besi sebanyak 1 tablet setiap hari/ 90 tablet selama kehamilan. ${ }^{5}$

Zat besi merupakan salah satu mineral alami yang terkandung didalam makanan dan tersedia pula dalam bentuk suplemen. Manfaat zat besi untuk tubuh, diantaranya membantu menjaga tubuh agar tidak mengalami anemia. ${ }^{6}$ Kebutuhan zat besi lebih besar setelah pertengahan kehamilan, karena itu kebutuhan zat besi tidak akan terpenuhi tanpa pemberian suplemen besi, tanpa suplementasi, konsentrasi $\mathrm{Hb}$ dan Hematokrit (Ht) turun bermakna seiring dengan peningkatan volume darah. ${ }^{7}$

Ibu hamil yang kekurangan cadangan zat besi dapat menyebabkan anemia defisiensi zat besi. Jumlah Fe yang dikonsumsi oleh ibu hamil selama kehamilan ada hubungannya dengan angka kejadian anemia dalam kehamilan, ${ }^{8}$ dan peningkatan $\mathrm{Hb}$ setelah mengkonsumsi tablet $\mathrm{Fe}^{9}$

Data WHO jumlah populasi yang mengalami anemia diseluruh Dunia adalah sebesar 83,2\% dari 114 negara, sedangkan untuk Asia Tenggara sebesar $97,8 \%$, anemia pada ibu hamil di Indonesia menempati urutan ke empat bersama dengan Thailand yaitu $30 \%$, angka ini lebih tinggi dari Malaysia dan Singapura yaitu $27 \%$ dan 28\%. World Health Organization (WHO) melaporkan bahwa terdapat 52\% ibu hamil mengalami anemia di negara berkembang. ${ }^{10,11}$ Kematian ibu dan neonatus pada tahun 2013 di Negara berkembang sekitar 3 juta dan 90.000 kematian disebabkan oleh anemia

\section{METODE}

Penelitian ini merupakan suatu penelitian observasional analitik dengan pendekatan pretest dan posttest kontrol group desain. Penelitian ini bertempat di Ilir Timur I Palembang, dilaksanakan Bulan November 2019- Januari 2020. Sampel pada penelitian ini adalah total sampling atau seluruh jumlah ibu hamil trimester dua di wilayah kerja ini berjumlah 16 reponden dan sesuai dengan kriteria inklusi: Ibu hamil trimester 2 defisiensi besi (WHO, 2015). Data hasil Riset Kesehatan Dasar (RISKESDAS) menunjukkan prevalensi anemia pada ibu hamil di Indonesia sebesar $37,1 \%$, data ini menunjukkan bahwa anemia gizi besi masih menjadi masalah kesehatan masyarakat. ${ }^{12}$

Angka kejadian anemia ibu hamil pada trimester I adalah $20 \%$, trimester II sebesar $70 \%$, dan trimester III sebesar $70 \%$, ini disebabkan Tubuh akan menggunakan zat besi dalam jumlah besar selama trimester kedua kehamilan. Kebutuhan akan meningkat dari hanya $0,8 \mathrm{mg}$ per hari selama trimester pertama, menjadi 6-7 mg dan volume darah akan meningkat sampai 35\% memasuki trimester dua dan ketiga, ini ekuivalen dengan $450 \mathrm{mg}$ zat besi untuk memproduksi selsel darah merah. Sel darah merah harus mengangkut oksigen lebih banyak untuk janin. Sedangkan saat melahirkan, perlu tambahan besi 300 - 350 mg akibat kehilangan darah. ${ }^{7}$

Data dinas kesehatan kota Palembang pada tahun 2012 angka kejadian anemia sebanyak $1.017(3,10 \%)$ ibu hamil dari 31.502 ibu hamil, jumlah ibu hamil dengan anemia pada tahun 2013 sebanyak 1.001 (3,0\%) dari 32.302 ibu hamil, tahun 2014 jumlah ibu hamil dengan anemia sebanyak1.028 (3,0\%) dari 33.309 ibu hamil. ${ }^{13}$ Setiap ibu hamil dianjurkan minum tablet tambah darah selama masa kehamilannya dan empat puluh hari setelah melahirkan. Cakupan pemberian Fe1 (30 tablet) untuk kota Palembang Tahun 2017 sebesar 99,12\% dan Fe-3 (90 tablet) sebesar 97,23\%. Cakupan pemberian $\mathrm{Fe}-1$ tertinggi di Kecamatan Plaju dan terendah di Kecamatan Ilir Timur I. ${ }^{14}$

Peneliti tertarik berdasarkan uraian diatas untuk mengadakan penelitian tentang "Tablet Fe terhadap Kadar Hemoglobin". Tujuan penelitian ini adalah untuk mengetahui "Pengaruh Konsumsi Tablet Fe terhadap Kadar Hemoglobin Ibu Hamil Trimester Dua".

(usia kehamilan 13-27 minggu) yang bersedia menjadi responden dan meminum tablet besi selama 30 hari, Ibu hamil tunggal yang didapatkan dari hasil pemeriksaan fisik, Ibu primigravida (hamil anak pertama) atau ibu multigravida (hamil anak ke dua-empat). Kriteria ekslusi pada penelitian ini: Ibu hamil dengan komplikasi, Ibu yang lupa minum 1 tablet besi/ lebih selama penelitian, Ibu sakit saat sedang dilakukan 
penelitian, dan Ibu tidak bisa dihubungi/ ditemui saat sedang dilakukan penelitian.

Data yang dikumpulkan pada penelitian ini adalah data primer. Data diperoleh dengan melakukan observasi pada ibu hamil yaitu berupa biodata, dan pengambilan serum darah untuk pemeriksaan kadar hemoglobin. Cara ukur kadar hemoglobin menggunakan metoda Hematology Analyzer. Analisis data dilakukan secara bertahap yang meliputi analisis univariat untuk mengetahui

\section{HASIL}

Berdasarkan Tabel 1. diketahui bahwa dari 16 responden mayoritas berpendidikan SMA berjumlah 8 orang $(50 \%)$, mayoritas Gravida distribusi frekuensi dari setiap masing - masing variabel yang disajikan dalam bentuk frekuensi dan persentasi. Analisis Bivariat Peneliti melakukan uji normalitas terlebih dahulu. Hasil didapatkan distribusi data normal, dilanjutkan uji statistik menggunakan uji Paired Sample T-Test untuk melihat perbedaan kadar hemoglobin sebelum dan sesudah minum tablet besi selama 30 hari.

responden multigravida sebanyak 10 orang $(62,5 \%)$, dan mayoritas umur responden 20-35 tahun sebanyak 15 orang $(93,8 \%)$.

Tabel 1. Hasil Analisis Univariat ( $\mathrm{n}=16)$

\begin{tabular}{lcc}
\hline Variabel & Jumlah & $\begin{array}{c}\text { Presentase } \\
(\mathbf{\%})\end{array}$ \\
\hline Karakteristik Ibu & & \\
Hamil & 0 & $\mathbf{0}$ \\
Pendidikan & 1 & 6,2 \\
$\quad$ - SD & 8 & 50 \\
- SLTP & 7 & 43,8 \\
- SMA & & \\
- PT & 6 & 37,5 \\
Gravida & 10 & 62,5 \\
$\quad$ - Primigravida & & \\
- Multigravida & 15 & 93,8 \\
Umur & 1 & 6,2 \\
$\quad$ - 20-35 tahun & & \\
- $\geq 35$ tahun &
\end{tabular}

Berdasarkan Tabel 2. Hasil analisis statistik menunjukkan bahwa rerata kadar hemoglobin pada ibu hamil trimester II sesudah mengkonsumsi 30 tablet $\mathrm{Fe}$ tidak mengalami kenaikan kadar hemoglobin dibandingkan dengan ibu hamil sebelum mengkonsumsi tablet Fe (besi). Analisis menunjukkan bahwa tidak terdapat perbedaan kadar hemoglobin pada ibu hamil trimester II sebelum dan sesudah mengkonsumsi 30 tablet Fe (besi) dengan nilai $p=0.079$.

Tabel 2. Pengaruh Konsumsi Tablet Fe terhadap Kadar Hemoglobin $(\mathbf{n}=16)$

\begin{tabular}{lcccc}
\hline \multirow{2}{*}{ Jumlah Tablet Fe } & Kadar Haemoglobin $(\mathbf{g} / \mathbf{d l})$ & \multicolumn{2}{c}{ Jumlah } & \multirow{2}{*}{ Nilai p } \\
\cline { 2 - 4 } & Rerata \pm SD & n & \% & \\
\hline 0 Tablet & $12,26 \pm 0,99$ & 16 & 100 & 0,079 \\
30 Tablet & $11,96 \pm 0,67$ & 16 & 100 & \\
& & & & \\
\hline
\end{tabular}




\section{PEMBAHASAN}

Tidak semua Bidan memberikan zat besi pada ibu hamil untuk dikonsumsi setiap hari dengan alasan mual pada masa kehamilan, tapi ada juga Bidan yang memberikan zat besi secara berkala, hasil peneltiian ini menunjukan tidak ada hubungan pola konsumsi zat besi dengan kadar hemoglobin pada ibu hamil 32 minggu. ${ }^{15}$

Zat besi $(\mathrm{Fe})$ adalah salah satu unsur yang paling banyak di kerak bumi, sehingga defisiensi zat besi (fe) merupakan penyebab anemia yang paling sering menyerang sekitar 500 juta orang di seluruh dunia. Kebutuhan zat besi (Fe) yang diperlukan tiap hari untuk mengkompensasi kehilangan dari tubuh dan untuk pertumbuhan bervariasi, kebutuhan yang paling besar pada ibu hamil, remaja dan wanita yang menstruasi. ${ }^{4}$

Selama kehamilan kebutuhan zat besi $(\mathrm{Fe})$ rata- rata sekitar $1000 \mathrm{mg}$. kira -kira 500 mg diperlukan untuk meningkatkan massa sel darah merah, dan sekitar $300 \mathrm{mg}$ ditransportasikan ke janin, terutama pada 12 minggu terakhir kehamilan. Sisa $200 \mathrm{mg}$ dibutuhkan untuk mengkompensasi kehilangan yang tidak disadari melalui kulit, feses, dan urine. ${ }^{16,17}$

Wanita sehat yang tidak hamil memiliki cadangan zat besi dengan konsentrasi hemoglobin rata- rata menurun dari $13,3 \mathrm{~g} / \mathrm{dl}$ menjadi $11 \mathrm{~g} / \mathrm{dl}$ diawal kehamilan. Peningkatan kebutuhan zat besi terjadi pada pertengahan kehamilan (trimester dua), dengan rata-rata 6-7 $\mathrm{mg}$ per hari, pada sebagian besar wanita, jumlah ini tidak terdapat di dalam tubuhnya. ${ }^{17}$

Namun demikian, jika ibu memasuki masa kehamilan dengan deplesi cadangan zat besi, sekalipun terdapat peningkatan diabsorbsi zat besi dari usus dalam jumlah sedang, jumlah zat besi yang diabsorbasi dari diet ditambah zat besi yang berasal dari cadangan tubuh kemungkinan tidak akan cukup untuk memenuhi kebutuhan zat besi selama kehamilan. ${ }^{17}$

Intervensi pada penelitian ini dilakukan dengan pemberian zat besi dalam sediaan ferrous fumarate $180 \mathrm{mg}$ (equivalent to elemental iron 60 mg). Terapi besi sering diperlukan jika hemoglobin $(\mathrm{Hb})$ turun dibawah $10 \mathrm{~g} / \mathrm{dl}$ pada kehamilan trimester II (dua) dan III (tiga). Sediaan terbaik zat besi adalah sulfas ferrosus yang mengandung $67 \mathrm{mg}$ zat besi (Fe) dalam tiap tablet $200 \mathrm{mg}$, harganya murah dan paling baik diberikan saat perut kosong dengan dosis yang berjarak 6 jam. Ferrous fumarate sama- sama murah dan efektif. Jika timbul efek samping dapat dikurangi dengan memberikan zat besi bersama makanan atau menggunakan sediaan ferro glukonat yang mengandung $36 \mathrm{mg}$ zat besi pertablet $300 \mathrm{mg}$. Terapi besi oral harus diberikan cukup lama untuk mengkoreksi anemia dan memulihkan cadangan besi tubuh. ${ }^{18}$

Suplementasi zat besi pada wanita hamil dalam formulasi kapsul dibandingkan dengan formulasi tablet menghasilkan lebih banyak peningkatan kadar hemoglobin darah, namun hasil uji statstik tidak terbukti secara signifikan. ${ }^{19}$

Pemerintah telah melakukan suatu program yang sangat baik untuk semua ibu hamil di seluruh Indonesia, program yang telah dilakukan adalah semua ibu hamil harus mengkonsumsi tablet Fe sebanyak 90 tablet selama kehamilannya. Tujuan suplementasi zat besi adalah mempertahankan cadangan zat besi untuk mencegah terjadinya anemia sejati, dan bukan untuk meningkatkan kadar hemoglobin. Kurangnya suplementasi zat besi dikaitkan dengan hasil peningkatan defisiensi besi sedang dan berat, karena meningkatnya kebutuhan zat besi selama kehamilan maka setiap ibu hamil harus mendapat tambahan suplemen zat besi, dan ini dapat dijadikan sebagai strategi pencegahan terjadinya anemia. $^{20}$

Suplementasi zat besi sebanyak 30-60 mg diberikan kepada ibu yang memiliki cadangan zat besi di dalam tubuhnya dan 120-240 mg per hari untuk ibu yang tidak memiliki cadangan zat besi. ${ }^{17}$ Karena jumlah besi yang diberikan pada janin dari ibu yang kekurangan besi tidak jauh berbeda dari jumlah yang di transfer secara normal, bayi yang baru lahir dengan ibu anemia berat tidak menderita anemia defisiensi besi. ${ }^{21}$

Penyerapan tablet besi ini banyak dipengaruhi oleh berbagai faktor diantaranya penyakit yang menyertai ibu selama kehamilan dan juga konsumsi Vitamin $\mathrm{C}$ dapat membantu tubuh menyerap zat besi dari makanan. Beberapa makanan yang mengurangi kemampuan menyerap zat besi seperti teh, kopi, coklat dan makanan yang mengandung kalsium serta produk susu lainnya. Penyerapan zat besi terjadi di Duodenum, apabila penyerapan berlangsung baik maka akan terjadi peningkatan Fe di dalam darah, yang selanjutnya akan meningkatkan kadar hemoglobin di dalam darah. ${ }^{7}$

Diet seimbang yang baik sangat penting untuk memastikan ibu hamil menerima cukup zat besi. Zat besi yang paling mudah diserap berasal dari daging merah, ikan dan unggas. Namun, ada pilihan vegetarian sayuran berdaun hijau seperti bayam. Efek samping yang paling umum dari mengkonsumsi tablet besi adalah mual, kembung, sembelit. Respon terhadap pengobatan setelah 2-4 minggu ibu hamil akan menjalani tes darah untuk memeriksa apakah tablet besi bekerja. Jika ada perubahan signifikan maka ibu hamil terus melanjutkan konsumsi tablet besi selama 3 bulan lagi, untuk membantu meningkatkan simpanan 
besi di dalam tubuh. ${ }^{22}$

Penyebaran dan pengangkutan besi sebagian besar diperantarai oleh 3 (tiga) protein; transferrin, reseptor tranferin 1 (TfR1) dan ferritin. Tiap- tiap molekul trnsferin dapat mengandung duo atom zat besi. Hanya sebagian kecil besi transferrin plasma yang berasal dari besi yang bersumber dari makanan yang diserap melalui duodenum dan jejenum. Besi dalam ferritin dan hemosiderin adalah dalam bentuk ferri. Besi ini dimobilisasi setelah direduksi kebentuk ferro dengan keterlibatan vitamin $\mathrm{C}^{4}$

Besi terdapat dalam makanan sebagai ferri hidroksida, baik kandungan besi maupun proporsi besi yang diserap oleh tubuh berbeda- beda antara makanan, secara umum, daging, khususnya hati merupakan sumber yang lebih baik dibandingkan sayuran, telur maupun produk susu. Diet di Negara Barat rata- rata mengandung 10-15 mg besi tiap hari, hanya 5- 10\% yang diserap pada keadaan normal. Perbandingan ini dapat meningkat sampai $20-30 \%$ pada ibu hamil atau defisiensi besi, tetapi bahkan dalam kondisi tersebut, sebagian besar besi dari makanan tetap tidak diserap. ${ }^{4}$

Menurut Center for Deases Control and Prevention (CDC) mendefinisikan anemia sebagai kondisi dengan kadar hemoglobin kurang dari $11 \mathrm{~g} / \mathrm{dl}$ pada trimester pertama dan ketiga dan kurang dari $10,5 \mathrm{~g} / \mathrm{dl}$ pada trimester kedua. ${ }^{20} \mathrm{Ibu}$ hamil dengan konsentrasi zat besi yang tinggi, tampaknya bahwa pemberian tablet besi harus dibatasi. ${ }^{23}$ Selain pemeriksaan kadar hemoglobin, ibu hamil juga penting dilakukan pemeriksaan ferritin. Status ferritin dalam darah rendah, ini menegaskan bahwa tubuh tidak punya cukup zat besi. ${ }^{24}$ Suplementasi zat besi selama kehamilan pada wanita hamil yang tidak anemia tetapi memiliki kadar ferritin rendah, pemeriksaan

\section{KESIMPULAN DAN SARAN}

Tablet besi mempunyai peranan penting dalam menentukan status besi pada tubuh, hasil penelitian ini menunjukkan tidak ada perbedaan kadar hemoglobin pada ibu hamil trimester II setelah mengkonsumsi 30 tablet besi namun kadar hemoglobin ibu dalam batas normal, dengan adanya zat besi yang cukup pada ibu hamil maka keseimbangan akan zat besi tetap terjaga dalam batas normal dan mencegah terjadinya anemia ferritin dapat bermanfaat untuk pencegahan anemia defiseinsi zat besi. ${ }^{25}$

Suplementasi zat besi oral adalah standar perawatan dalam praktik kebidanan pada kehamilan. Terapi zat besi oral banyak dipengaruhi faktor seperti penyerapan terbatas, tolerabilitas rendah, ketidakpatuhan dan efek samping. Hasil penelitian ini menunjukan bahwa peningkatan kadar hemoglobin lebih banyak terjadi pada ibu yang diberikan zat besi secara intravena dari pada diberikan secara oral. ${ }^{26}$

Selama kehamilan, asupan zat besi juga meningkat, ini diperlukan untuk perkembangan janin dan plasenta terutama pada ibu hamil trimester dua dan tiga. Selama kehamilan normal terjadi peningkatan volume plasma sebanyak 30$50 \%$, peningkatan masa sel darah merah sebanyak 20-30\%, dan terjadi penurunan konsentrasi hemoglobin karena itu diperlukan keseimbangan zat besi didalam tubuh selama kehamilan. ${ }^{27}$ Penelitian lain menyatakan ada hubungan signifikan antara kadar hemoglobin ibu hamil dengan hasil kehamilan seperti berat bayi baru lahir, dan kelahiran premature. ${ }^{28}$ Namun anemia terjadi tidak hanya pada wanita hamil tetapi ditemukan pada pekerja wanita usia produktif. ${ }^{29,30}$

Hasil penelitian lain menyatakan bahwa ada hubungan kejadian anemia pada ibu hamil trimester III dengan jumlah $\mathrm{Fe}$ yang dikonsumsi selama kehamilan, ibu hamil yang mengkonsumsi fe minimal 90 tablet selama kehamilan dapat menurunkan angka kejadian anemia. ${ }^{8,31}$ Oleh karena itu pemberian tablet besi penting juga dikonsumsi oleh pekerja wanita dengan usia produktif untuk mengantispasi penurunan kadar hemoglobin.

defisiensi besi.

Konsumsi zat besi banyak faktor yang mempengaruhi penyerapannya karena itu, sebaiknya setelah 30 hari kadar hemoglobin harus dikoreksi untuk dilakukan peninjauan lebih lanjut apakah tablet besi bekerja, apabila hasilnya baik dapat diteruskan pemberian sampai 90 tablet, sebaliknya apabila tidak bekerja dapat dilakukan penilaian lebih lanjut penyebabnya. 


\section{DAFTAR PUSTAKA}

1. Sherwood L. 2011. Fisiologi Manusia dari sel ke sel. Jakarta: EGC

2. World Health Organization. 2011. Serum ferritin Concentrations For The Assaament of Iron Status and Iron Deficiency in Populations. Geneva: World Health Organization

3. Feryanto FA. 2014. Asuhan Kehamilan patologis. Jakarta: Salemba Madika

4. Hoffbrand AV and Moss PA. 2018. Kapita Selekta Hematologi. Jakarta: EGC

5. Kementerian Kesehatan RI. 2017. Profil Kesehatan Indonesia 2016. Jakarta: Kementerian Kesehatan RI

6. Sudargo T, Muhammad HF, Kandarina I, Putri N, Irianto, S, Pranoto YA, Paramastri R. 2018. The effect of additional egg supplementation on vitamin and mineral fortification program on growth, cognitive development and hemoglobin in Indonesian underweight and stunting children. Nutrition $n$ Food Science, 48(5): 744-754

7. Cunningham FG, Leveno KJ, Bloom SL, Hauth JC, Gilstrap III LC, Wenstrom KD. 2014. Obstetri William Edisi 24. Jakarta: EGC

8. Darwanty J. 2018. Hubungan Konsumsi Fe Terhadap Kejadian Anemia pada Ibu Hamil di Kabupaten Karawang tahun 2014. Jurnal kebidanan, 7(1): 14-22

9. Nurhayati, Halimatusakdiah, Asniah. 2014. Pengaruh Asupan Tablet Besi (Fe) Terhadap Kadar Haemoglobin $(\mathrm{Hb})$ pada Ibu Hamil di Puskesmas Kopelma Darussalam Tahun 2014. Idea Nursing Journal, 6 (3).

10. World Health Organization. 2014. Global Nutrition Targets 2025 Policy Brief Series. World Health Organization

11.World Health Organization. 2015. The Global Prevalence of Anemia in 2011. Geneva: World Health Organization.

12.Kementerian Kesehatan RI. 2013. RISKESDAS 2013 Badan Penelitian dan Pengembangan Kesehatan Kemenkes RI. Jakarta: Kementerian Kesehatan RI

13.Dinas Kesehatan Kota Palembang. 2014. Profil Kesehatan Tahun 2013. Palembang: Dinas Kesehatan Kota Palembang

14.Dinas Kesehatan Kota Palembang. 2018. Profil Kesehatan Tahun 2017. Palembang: Dinas Kesehatan Kota Palembang.

15.Anggraeni S. 2018. Hubungan Pola Konsumsi Zat Besi dengan Kadar Hemoglobin pada Ibu Hamil di BPS Kabupaten Pringsewu Lampung Tahun 2015. Midwifery Journal, 3(1): 86-89

16. Sharma JB, and Shankar M. Anemia in Pregnancy. JIMSA 2010, 23(4): 253-60.
17.Fraser DM, dan Cooper MA. 2009. Myles Buku Ajar Bidan Edisi 14. Jakarta: EGC

18. Varney H, Krebs Jan M, Gegor Carolyn L. 2004. Buku Ajar Asuhan Kebidanan Edisi 4 Vol 1. Jakarta:EGC

19. Srivastava R, Kant S, Singh AK,Saxena R, Yadav K,Pandav CS. 2019. Effect of Iron and Folid Acid Tablet Versus Capsule Formulation on Treatment Compliance and Iron Status Among Pregnant Women: A randomized Controlled Trial. J Family Med Prim Care, 8(2): 378-384

20.Loy SL, Lim LM, Chan SY, Tan PT, Chee YL, Quah PL et al. 2019. Iron status and risk factors of iron deficiency among pregnant women in Singapore: a cross-sectional study. BMC Public Health, no:397

21.Leveno Kenneth JMD. 2015. Manual Williams Komplikasi Kehamilan Ed 23. Jakarta: EGC

22.Colman K and Pavord S. 2017. Iron Deficiency Anaemia in Pregnancy Information for Patients. Oxford University Hospitals.

23. Alizadeh L, and Salehi L. 2016. Is Routine Iron Supplementation Necessary in Pregnant Woman with High Hemoglobin?. Iranian Red Crescent edical Journal, 18(1): e59314

24.Daru J, Colman K, Stanworth SJ, Salle BD, Wood EM, Pasricha SR. Serum ferritin as an indicator of iron status: what do we need to know?. The American Journal of Clinical Nutrition 2017, 106(6): 1634S-1639S.

25.Falahi E, Akbari S, Ebrahimzadeh $F$ and Gargari BP. 2011. Impact of prophylactic iron supplementation in healthy pregnant women on maternal iron status and birth outcome. Food and Nutrition Bulletin, 32(3).

26.Dalal M, Goyal R, Nanda S, Dahiya P,Dahiya K, Madan S. 2018. Oral Versus Intravenous Iron for Treatment of Iron Deficiency Anemia in Pregnacy: A Randomized Controlled Trial. Indian Journal of Public Health Research \& Development, 9(6).

27.Fisher AL and Nemeth E. 2017. Iron Homeostasis during pregnancy. Am J Clin Nutr, 106 (suppl): 1567S-74S

28. Srour MA, Aqel SS, Srour KM, Younis KR, Samarah F. 2018. Prevalence of Anemia and Iron Deficiency among Palestinian Pregnant Women and Its Association with Pregnancy Outcome.https://doi.org/10.1155/2018/913562 5

29.Maksuk M, Pratiwi D, Amin M, Suzzana S. Kadar Hemoglobin Pekerja Penyemprot Gulma Akibat Paparan Pestisida Di Perkebunan Kelapa Sawit. JPP (Jurnal Kesehat Poltekkes Palembang). 2019;14(1 SE-Articles). doi:10.36086/jpp.v14i1.397. 
(JPP) Jurnal Kesehatan Poltekkes Palembang

Vol. 15, No. 1, Juni 2020, eISSN 2654-3427

DOI: $10.36086 / j p p . v 15 i 1.466$

30.Maksuk, Andani P, Suzanna, Amin M. Analisis Faktor Risiko Kejadian Anemia pada Aplikator Herbisida (Studi Kasus di Perkebunan Kelapa Sawit PT. S Kabupaten Banyuasin). JIKM [Internet]. 2017;8(1).
Availablefrom:http://ejournal.fkm.unsri.ac.id/i ndex.php/jikm/article/view/229

31.Azra AP, Rosha BC. 2015. Faktor-Faktor yang Berhubungan dengan Status Anemia Ibu Hamil di Wilayah Kerja Puskesmas Air Dingin Kecamatan Koto Tangah Kota Padang.: 89-95. 